\title{
Materiality in the Future of History: Things, Practices, and Politics
}

\author{
Frank Trentmann
}

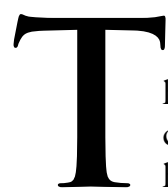

hings are back. After the turn to discourse and signs in the late twentieth century, there is a new fascination with the material stuff of life. Things have recaptured our imagination, from Jane Campion's film The Piano (1993), biographies of objects, and exhibitions in the Fifth Berlin Biennial for Contemporary Art, "When Things Cast No Shadow" (2008), all the way to public debates about the transformation of human flesh and mind in an age of nanotechnology, cloning, and cyborgs. ${ }^{1}$ Unlike the linguistic turn, however, with its roots in poststructural thought, the material turn has multiple sources. In anthropology, the revival of interest in material culture in the 1980s came in part through a rapprochement with paleoanthropology, in part through a Marxian rediscovery of the importance of objects in the creation of social worlds. ${ }^{2}$ Literary

Frank Trentmann is professor of history at Birkbeck College, University of London. From 2002 to 2007, he was director of the $£ 5$ million Cultures of Consumption research program, cofunded by the Arts and Humanities Research Council and the Economic and Social Research Council (ESRC). He is working on a book for Penguin, The Consuming Passion: How Things Came to Seduce, Enrich, and Define Our Lives, from the Seventeenth Century to the Twenty-First. This article is one of a pair seeking to facilitate greater exchange between history and the social sciences. Its twin- "Crossing Divides: Globalization and Consumption in History" (forthcoming in the Handbook of Globalization Studies, ed. Bryan Turner) - shows what social scientists (and contemporary historians) might learn from earlier histories. The piece here follows the flow in the other direction. Many thanks to the ESRC for grant number RES-052-27-002 and, for their comments, to Heather Chappells, Steve Pincus, Elizabeth Shove, and the editor and the reviewer.

${ }^{1}$ Annie Proulx, Accordion Crimes (London, 1997); Donna Haraway, "A Cyborg Manifesto: Science, Technology, and Socialist-Feminism in the Late Twentieth Century," in Simians, Cyborgs and Women: The Reinvention of Nature (New York, 1991), 149-81.

${ }^{2}$ Christopher Tilley, Webb Keane, Susanne Küchler, Michael Rowlands, and Patricia Spyer, eds., Handbook of Material Culture (London, 2006); Wim M. J. van Binsbergen, "Introduction," in Commodification: Things, Agency, and Identities (the Social Life of Things Revisited), ed. Wim M. J. van Binsbergen and Peter L. Geschiere (Münster, 2005), 9-51; Daniel Miller, ed., Material Cultures: Why Some Things Matter (London, 1998); Victor Buchli, ed., The Material Culture Reader (Oxford, 2002). An early, influential commodity biography was Sidney Mintz, Sweetness and Power: The Place of Sugar in Modern History (New York, 1985); the genre peaked in the 1990s with biographies of cod, pineapple,

Journal of British Studies 48 (April 2009): 283-307

(C) 2009 by The North American Conference on British Studies.

All rights reserved. 0021-9371/2009/4802-0002\$10.00 
scholars rediscovered the world of things and traced the patina it left on human relations and sensibilities. ${ }^{3}$ In sociology, meanwhile, interest in materiality has above all been stimulated by a recognition of the social construction of science and technology. Studies have shown how instruments help generate the social world of the laboratory, leading to an appreciation of things as "knots of socially sanctioned knowledge." ${ }^{4}$

The status of things has sparked a good deal of soul-searching that oscillates between fears that life is becoming dematerialized and a celebration of objects as "thought companions, as life companions." The divide between humans and things has been encroached upon. Most radically, greater humility toward things has led to calls for a more object-oriented democracy in which subaltern things will be liberated from the humanist rule of subject-centered discourse. ${ }^{6}$ Like words in the postmodern 1980s, things today are shaking our fundamental understandings of subjectivity, agency, emotions, and the relations between humans and nonhumans.

These changes have implications for historical method, but perhaps especially so for Anglo American histories. There can hardly be another place and time with such rich accounts of material culture as eighteenth-century Britain and colonial America. Alongside inventories, we have histories of taste and aesthetics, studies of shopping, and discussions of possessions and heirlooms in the construction of social, gender, and family identities. ${ }^{7}$ The origins of this tradition of material culture

salt, and others. See also Robert J. Foster, “Tracking Globalization: Commodities and Value in Motion," in Tilley et al., Handbook of Material Culture.

${ }^{3}$ See Bill Brown, ed., "Things," special issue, Critical Inquiry 28, no. 1 (Autumn 2001), and $A$ Sense of Things: The Object Matter of American Literature (Chicago, 2003).

${ }^{4}$ Alex Preda, "The Turn to Things: Arguments for a Sociological Theory of Things," Sociological Quarterly 40, no. 2 (Spring 1999): 347-66, quote at 347; Bruno Latour and Steve Woolgar, Laboratory Life: The Social Construction of Scientific Facts (Beverly Hills, CA, 1979); Wiebe E. Bijker, Thomas P. Hughes, and Trevor Pinch, eds., The Social Construction of Technological Systems (Cambridge, MA, 1987); Tim Dant, Materiality and Society (Maidenhead, 2005); Bruno Latour, "When Things Strike Back: A Possible Contribution of 'Science Studies' to the Social Sciences," British Journal of Sociology 51, no. 1 (2000): 107-23. See also James Livesey, "Material Culture, Economic Institutions and Peasant Revolution in Lower Languedoc, 1770-1840," Past and Present, no. 182 (February 2004): 143-73; Marc Levinson, The Box: How the Shipping Container Made the World Smaller and the World Economy Bigger (Princeton, NJ, 2006).

${ }^{5}$ Sherry Turkle, ed., Evocative Objects: Things We Think With (Cambridge, MA, 2007), 9.

${ }^{6}$ Bruno Latour, "From Realpolitik to Dingpolitik," in Making Things Public: Atmospheres of Democracy, ed. Bruno Latour and Peter Weibel (Cambridge, MA, 2005); Bjornar Olsen, "Material Culture after Text: Re-membering Things," Norwegian Archaeological Review 36, no. 2 (2003): 87-104; Ewa Domanska, "The Material Presence of the Past," History and Theory, no. 45 (October 2006): 337-48.

${ }^{7}$ From the large body of literature, see Neil McKendrick, John Brewer, and J. H. Plumb, The Birth of a Consumer Society: The Commercialization of Eighteenth-Century England (Bloomington, IN, 1982); John Brewer and Roy Porter, eds., Consumption and the World of Goods (London, 1993); Lorna Weatherill, Consumer Behaviour and Material Culture in Britain, 1660-1760, 2nd ed. (London, 1996); Woodruff D. Smith, Consumption and the Making of Respectability, 1600-1800 (London, 2002); Linda Levy Peck, Consuming Splendor: Society and Culture in Seventeenth-Century England (Cambridge, 2005); Laurel Thatcher Ulrich, The Age of Homespun: Objects and Stories in the Creation of an American Myth (New York, 2001); Amanda Vickery and John Styles, eds., Gender, Taste, and Material Culture in Britain and North America, 1700-1830 (New Haven, CT, 2006); Ilana Krausman Ben-Amos, The Culture of Giving: Informal Support and Gift-Exchange in Early Modern England (Cambridge, 2008); H. R. French, The Middle Sort of People in Provincial England, 1600-1750 (Oxford, 2007); Ann Smart Martin, Buying into the World of Goods: Early Consumers in Backcountry Virginia (Baltimore, 2008). 
studies can be traced back to folklore and museum studies, especially in the United States. In recent years, research has moved at once forward in time, highlighting the cult of home possessions in Victorian Britain, and outward, recognizing imperial and global points of exchange and transculturation. ${ }^{8}$ Such studies have greatly enriched our understanding of globalization and consumption. ${ }^{9}$

At the same time, there has been remarkably little reverse flow of new approaches to materiality from neighboring disciplines into history. Arguably, the very success of eighteenth-century material culture studies has had a conservative side effect. Most scholars have tended to take as given what material culture is and how to study it. They have examined more groups and more objects in more places and times, but the research agenda has remained remarkably unchanging. It has resulted in a widening gulf between material culture, focused on identities and representations, and material politics and political economy. Meanwhile, scholars elsewhere have moved on. In France, there has been cross-fertilization between the Annales school, scholars of everyday practices, and the choisistes. ${ }^{10}$ In British studies, collaboration between historians and sociologists, anthropologists, or geographers remains rare. ${ }^{11}$ A prominent exception is the exchange between histories of science and science and technology studies. ${ }^{12}$

What should be done? I have poached the title of these reflections from Arjun Appadurai, who in 2005, twenty years after the publication of the seminal Social Life of Things, inquired about "materiality in the future of anthropology." Appadurai noted that work on how things mutate back and forth between commodities, gifts, and other forms "now seems quaint," "somewhat aloof from wider debates about new technologies, new global economies and new civilizing forms and techniques." Instead of sticking to the biography of individual objects, he

For a critique, see Richard Grassby, "Material Culture and Cultural History," Journal of Interdisciplinary History 35, no. 4 (Spring 2005): 591-603.

${ }^{8}$ Clive Edwards, Turning Houses into Homes: A History of the Retailing and Consumption of Domestic Furnishings (Aldershot, 2005); Deborah Cohen, Household Gods: The British and Their Possessions (New Haven, CT, 2006); Maxine Berg, "In Pursuit of Luxury: Global History and British Consumer Goods in the Eighteenth Century," Past and Present, no. 182 (February 2004): 85-142, and Luxury and Pleasure in Eighteenth-Century Britain (Oxford, 2005); Robert Batchelor, "Concealing the Bounds: Imagining the British Nation through China," in The Global Eighteenth Century, ed. Felicity A. Nussbaum (Baltimore, 2003); Maya Jasanoff, Edge of Empire: Lives, Culture, and Conquest in the East, 1750-1850 (New York, 2005); Margot C. Finn, "Colonial Gifts: Family Politics and the Exchange of Goods in British India," Modern Asian Studies 40, no. l (2006): 203-31; John Brewer and Frank Trentmann, eds., Consuming Cultures, Global Perspectives (Oxford, 2006).

${ }^{9}$ Frank Trentmann, "Crossing Divides: Globalization and Consumption in History," in Handbook of Globalization Studies, ed. Bryan Turner (London, 2009), forthcoming.

${ }^{10}$ Michael Sheringham, Everyday Life: Theories and Practices from Surrealism to the Present (Oxford, 2006). To identify such general trends, of course, does not mean that there are no individual traces in British studies, such as Raphael Samuel, Theatres of Memory (London, 1996); and Keith Wrightson, Earthly Necessities: Economic Lives in Early Modern Britain, 1470-1750 (London, 2002).

${ }^{11}$ Examples are the Domestic Interiors project (Arts and Humanities Research Council [AHRC] and the Victoria and Albert Museum; http://www.rca.ac.uk/csdi/) and the Cultures of Consumption program (Economic and Social Research Council and AHRC; http://www.consume.bbk.ac.uk).

${ }^{12}$ Lorraine Daston, Things That Talk (Chicago, 2000). The ZKM Karlsruhe exhibit and publication (Latour and Weibel, Making Things Public) included Loraine Daston, Peter Galison, and Simon Schaffer. 
urged anthropologists to follow the systemic presence of materiality in global political economy, space, and security. ${ }^{13}$

The question for historians is, I believe, similarly not whether Marx's concern with commodities and Mauss's with gifts have ceased to matter-they have not. Rather, it is to confront the material turnings around us and to ask how they might illuminate further the role of things in the past. My concern, therefore, is not to outline a single new agenda but to bring historical research into greater dialogue with other approaches. To avoid further misunderstanding, let me emphasize that I am interested in materiality - not consumption broadly defined. The latter literature now encompasses thousands of books and articles but until recently has been preoccupied with purchase, acquisition, and shopping rather than material use. ${ }^{14}$ There are three dimensions of materiality I want to explore: the essence of things, choice and practice, and material politics. The aim of the inquiry is thematic rather than chronological or comprehensive, and I have selected clusters of historical literature, such as the eighteenth century and recent interest in nineteenthcentury networks and technopolitics, not because they are exhaustive or typical for British studies in other periods but because they are useful for thinking about future directions of materiality. The discussion could be broadened to adjacent fields such as design history, fashion and museum studies, architecture, or the history of the book, but we must start somewhere. ${ }^{15}$

I begin by asking how things have been treated in the studies of the eighteenth century that have been so influential in historical approaches to material culture and bringing these treatments into dialogue with studies in neighboring disciplines. The historical embrace of things, I suggest, has been partial. The second theme concerns how people acquire and use things. New eighteenth-century studies have emphasized that many people did not exercise choice but were "involuntary consumers" of gifts, charities, and inheritance. ${ }^{16}$ The "practice turn" in the social sciences offers an intellectual toolbox for further exploring consumption as a set of practices, drawing our attention to habits, routines, and rhythms. At the same time, "choice" needs to be historicized. Finally, I suggest, connecting "hard" (but fragile) things and networks to the "soft" world of possessions and the domestic interior creates a space for material politics, reconnecting private and public and providing a bridge between histories of politics and material culture.

${ }^{13}$ Arjun Appadurai, "Materiality in the Future of Anthropology," in van Binsbergen and Geschiere, Commodification, 55-62.

${ }^{14}$ For a multidisciplinary bibliography, see "The Consumption Bibliography" on the Cultures of Consumption Web site, http://www.consume.bbk.ac.uk/publications.html\#bibliography.

${ }^{15}$ Points of entry include Regina Lee Blaszczyk, Imagining Consumers: Design and Innovation from Wedgwood to Corning (Baltimore, 2000); Lara Kriegel, Grand Designs: Labor, Empire, and the Museum in Victorian Culture (Durham, NC, 2007); Isobel Armstrong, Victorian Glassworlds: Glass Culture and the Imagination, 1830-1880 (Oxford, 2008); Christopher Breward, Becky Conekin, and Caroline Cox, eds., The Englishness of English Dress (Oxford, 2002); David Gilbert, ed., "Shopping Routes: Networks of Fashion Consumption in London's West End, 1945-1979," special issue, London Journal 31, no. 1 (June 2006); Annie Coombes, Reinventing Africa: Museum, Material Culture, and Popular Imagination in Late Victorian and Edwardian England (New Haven, CT, 1994); Tim Barringer and Tom Flynn, eds., Colonialism and the Object: Empire, Material Culture, and the Museum (London, 1998).

${ }^{16}$ The concept is that of John Styles; see Styles, The Dress of the People: Everyday Fashion in EighteenthCentury England (New Haven, CT, 2007). 


\section{THINGS AND OBJECTS}

Quilts, handkerchiefs, shoes, chintzes, porcelain cups, wallpaper, and cupboardsthese are the kinds of objects that crowd the pages of historical inquiries into the material culture of Georgian Britain and early America. Compare these with the range of things that find their way into discussions of material culture in neighboring disciplines. Evocative Objects, which considers the contribution of things to thoughts and emotions, includes knots, an apple, ballet slippers, and even singlecelled organisms (slime mold). ${ }^{17}$ Trying to find an answer to the question "How are things?" the philosopher Roger Pol-Droit examines his bed and his clothes, but also a tombstone, a paper clip, and the street lamp outside his window. ${ }^{18}$

Historians of eighteenth-century material culture have tended to concern themselves with a particular slice of the world of things. Domestic objects and personal possessions loom largest, especially soft furnishings, clothing, and furniture with a special meaning for personal and family identity, such as Hannah Barnard's cupboard studied by Laurel Thatcher Ulrich. ${ }^{19}$ Material culture mainly stops at the domestic doorstep, rarely connecting to urban networks, to the office, or to the brutal materiality of iron, steel, or bullets. The material world is mainly "soft," decorative, and visible.

John Styles and Amanda Vickery have noted the "gaps and mismatches" between American and British historiography: "Foodways, house forms, and domestic selfsufficiency, have been almost entirely ignored in British academic circles, until very recently." These differences, they suggest, "reflect the absence of a distinct academic field in Britain to play the role that material-culture studies have performed for the history of seventeenth- and eighteenth-century North America." ${ }^{20}$ Of course, this complaint is now outdated, given the publication of works such as Deborah Cohen's Household Gods (2006). It is also a surprising conclusion, given the flourishing of material culture studies in British anthropology and archaeology and the wave of work in sociology and science and technology studies since the 1980s. What we are dealing with is not the absence of an intellectual environment as such but the fact that few historians have joined it. The social science literature, in turn, has rarely seen it necessary to include historians in its anthologies. The Handbook of Material Culture (2006) includes thirty-three chapters, of which only one is by a historian; tellingly, it is about home furnishings, by Robert St. George, an expert on the domestic in New England. This does not mean that the past is missing in the social sciences. Rather, sociologists, anthropologists, geographers, and others tend to write about history with their own tools and concerns.

What are the reasons for this gulf? It would be wrong to simply invoke empiricism or historians' generic inability to connect soft and hard matter. After all, historians elsewhere like Fernand Braudel or Daniel Roche move between the

\footnotetext{
${ }^{17}$ Turkle, Evocative Objects.

${ }^{18}$ Roger Pol-Droit, How Are Things? A Philosophical Experiment, trans. Theo Cuffe (London, 2005).

${ }^{19}$ Laurel Thatcher Ulrich, "Hannah Barnard's Cupboard: Female Property and Identity in Eighteenth-Century New England," in Through a Glass Darkly: Reflections on Personal Identity in Early America, ed. Ronald Hoffman, Mechal Sobel, and Fredrika J. Teute (Chapel Hill, NC, 1997), 238-73.

${ }^{20}$ John Styles and Amanda Vickery, "Introduction," in Vickery and Styles, Gender, Taste, and Material Culture, 23.
} 
home, clothing, and infrastructures. ${ }^{21}$ Rather, I believe, it has to do with the dominant focus on symbolic communication. The main interest among eighteenthcentury British historians has been in objects as communicators of personal and social identities. A recent example is Ann Smart Martin's fascinating Buying into the World of Goods, which unfolds the commercialization of "backcountry Virginia." For instance, slaves bought looking glasses by selling chicken and produce. In her case study of the ribbon, Smart Martin notes that the ribbon can be easily displayed or hidden, but she is mainly interested in ribbons as "consummate desirable things," signs of emotional investment and attachment, and as gifts at a fair ("the fairing"). ${ }^{22}$

This interest in objects for symbolic communication has yielded a range of insights about identity formation, manners, and the cult of the domestic. Recent work by Vickery on wallpaper highlights the specific language of decorum, which associated "pretty" design with "neatness" and abhorred "showy" extravagance. ${ }^{23}$ Other work has shown how consumer goods changed meanings as they moved from one class to another. When workers and artisans dressed up in cotton, they did so within their own culture, not simply to emulate the middling sort. ${ }^{24}$

Both these strands can be read as challenges to the "conspicuous consumption" and "distinction" theses. Nonetheless, the research orientation retains the imprint of Thorstein Veblen and Pierre Bourdieu as major points of reference. Things are interesting because their appropriation promises to reveal processes of social stratification and identity formation. It is probably no coincidence that the hegemony of this approach to objects came at a time when questions of identity loomed so large in Western societies. The thing is a means to an end. It is not the starting point of inquiry, let alone its center. In short, historical material culture studies have been more about culture than about material. Objects are "bundles of meaning." But are they only that?

The boundaries of things are not as self-evident or fixed as we may wish. Some metaphysicians dispute that tables are "real" objects since they are ultimately composites of atoms, quarks, and empty spaces in between. ${ }^{25}$ But even outside metaphysics, things are ambivalent. Some scholars include tiny organisms, like the protist Dictyostelium chosen by Evelyn Fox Keller as her object to think with. Her slime mold is not an agent with a will or intentions, but neither is it like a table. It has a built-in program of development. ${ }^{26}$ Histories of material culture would no doubt look different if such organisms were admitted entry. Other objects live in a gray zone, moving back and forth between inanimate and animate existence. Clothes, for example, have a suppleness of movement that endow them with a kind of "half-life." "We live our clothes," Pol-Droit has written, "as though they

\footnotetext{
${ }^{21}$ Fernand Braudel, Civilization and Capitalism, 3 vols. (London, 1981-84); Daniel Roche, $A$ History of Everyday Things: The Birth of Consumption in France, 1600-1800, trans. Brian Pearce (Cambridge, 2000).

${ }^{22}$ Smart Martin, Buying, 9, 242, chap. 5.

${ }^{23}$ Amanda Vickery, "Neat and Not Too Showey': Words and Wallpaper in Regency England," in Vickery and Styles, Gender, Taste, and Material Culture, 201-24.

${ }^{24}$ Styles, Dress of the People. That consumption had cultural and class-specific forms was already emphasized by Maurice Halbwachs, L'Évolution des besoins dans les classes ouvrières (Paris, 1933).

${ }^{25}$ For a rebuttal, see Amie L. Thomasson, Ordinary Objects (Oxford, 2007).

${ }^{26}$ Evelyn Fox Keller, "Slime Mold," in Turkle, Evocative Objects, 298-306.
} 
were alive. Your trousers do the walking." They "are integrated into the body's memory."27

Other things have different kinds of qualities. A sponge is a thing that absorbs and releases other things. Boilers, pipes, and cables live a more concealed existence, except at moments of installation, maintenance, or breakdown. This diversity probably defeats a uniform theory or history of objects. Still, this brief discussion alerts us to two important dimensions. The first concerns the ambivalent status of many things that are neither dead nor alive. This challenges a view that things are passive objects or simply appropriated by people. The second relates to function. Alongside things that primarily signal meaning and identity, there are others that accomplish tasks or enable humans and other things to perform tasks. They create warmth or cold, enable mobility, store and release objects, or process communication. Many operate at several levels at once-a car symbolizes status, moves people and objects, provides a private space-time zone, and produces pollution.

So far, things and objects have been treated as synonymous. There are, however, intellectual traditions that draw distinctions between them. Mostly, things have been viewed as prior, more authentic, and less polluted than objects. Marx famously described how commodification transformed a table from an ordinary piece of wood into a transcendent object standing on its head, more mysterious than if it were dancing. ${ }^{28}$ Yet commodification only captures some of the extra qualities that things carry as objects. People give them distinct values and arrange them in assemblages. And these can change in the life of the same commodity. As Bill Brown has noted in his excavation of thingness in postbellum American literature, "Value derives from the appropriation of a pre-existing surplus, the material object's own excessiveness." ${ }^{29}$ In other words, "use-value"- a concept Marx employed only at an abstract level-obscures the concrete values that emerge in material culture but are not determined by an object's status as commodity as such.

Philosophers have long debated the boundaries between things and humans. In the twentieth century, Martin Heidegger and Maurice Merleau-Ponty in particular emphasized their embodied relationship. For Heidegger, things show their thingness only in the process of being put to use, literally proving their readiness to the human hand (Zubandenheit), whereas objects live in a state of distant presence or contemplation (Vorbandenheit). A hammer is known and experienced differently in the process of hammering than when it is lying unused in a cupboard or is being observed. When hammering, a person appropriates an object and turns it into a thing, releasing a form of embodied knowledge. Materiality is not distinct from human existence, or Dasein. It is part of an organic relationship. And it is an active process. ${ }^{30}$

Merleau-Ponty, similarly, emphasized the body as a material entity. Touch, sight,

${ }^{27}$ Pol-Droit, Things, 52-53, 74.

${ }^{28}$ Karl Marx, Das Kapital (Hamburg, 1867), bk. 1, chap. 1, sec. 4.

${ }^{29}$ Brown, Sense of Things, 14.

${ }^{30}$ Martin Heidegger, “Das Ding” (1950), in Vorträge und Aufsätze (Tübingen, 1954), 157-79, and Grundprobleme der Pbänomenologie (Tübingen, 1927). The hand and handling of things play a prominent place in Heidegger's thought, as does the wearing of shoes in revealing their thingness (Schubzeng). Another tradition is the social behaviorism of George Herbert Mead. See Mead, The Philosophy of the Act, ed. Charles Morris (Chicago, 1938); E. Doyle McCarthy, "Toward a Sociology of the Physical World: George Herbert Mead on Physical Objects," Studies in Symbolic Interaction 5 (1984): 105-21. 
and hearing create a sense of being and bodily knowledge that is through and through connected with the material world around it. Recent sociologists have used Merleau-Ponty's concepts of the "habit-body" to study how car mechanics rely on their bodily memory of tools, parts, and tasks. ${ }^{31}$ Although historians do not have the privilege of retroactive ethnography, the habit-body is a subject worthy of inquiry because nervous and motoric memories are built up, modified, or lost over time. In addition to the symbolic values people placed on things, the question then is also what they did with them and how these interactions shaped their materially embodied selves, practices, and relationships.

Such approaches to the embodied materiality of human action raise deeper questions about agency and causation fundamental to the discipline of history. Most historians have proceeded from human actors outward, asking how people in the past have assigned things meanings or put them to use. To focus, by contrast, on how things, hands, and senses come together points to a more open, fluid view of action. Here things play an active role too, weaving their way into material culture and human selfhood through practices that are more than simply the result of subjective decisions or intended meanings.

The most influential (if controversial) platform for exploring the "agency" of things in the past couple of decades has been actor-network theory (ANT). Spearheaded by Bruno Latour, Michel Callon, John Law, and others, ANT tries to transcend multiple dualities: between society and nature, between technology and society, and between human and nonhuman actors. "Students of technology are never faced with people on the one hand and things on the other," Latour has emphasized. "They are faced with programs of action, sections of which are endowed to parts of humans, while other sections are entrusted to parts of nonhumans." 32 Seeing agency as distributed between humans and objects demands the overhaul of "traditional" social theories that, according to Latour, have looked at the world through an anthropomorphic, object-alien prism left behind by the Enlightenment. "Society" and "the social" are not distinct domains but simply a set of ties in the assembly of networks composed of nature, things, tools, technologies, and humans.

In the past twenty years, ANT has grown into a formidable research network applied to an ever-growing range of subjects, from the laboratory to the electronic car all the way to alcoholic liver disease..$^{33}$ Evaluating this evolving corpus of research falls outside the aims of this article. However, ANT is interesting for our concerns because of its basic assumptions about the place of things in modernity. Latour's pleas to give things greater respect are backed up by an indictment of

\footnotetext{
${ }^{31}$ Dant, Materiality and Society, chap. 6.

${ }^{32}$ Bruno Latour, "Where Are the Missing Masses? The Sociology of a Few Mundane Artifacts," in Shaping Technology/Building Society, ed. Wiebe E. Bijker and John Law (Cambridge, MA, 1992), 225-58, quote at 254, emphasis in original. See also Latour, "When Things Strike Back."

${ }^{33}$ See the bibliography by John Law, "The Actor Network Resource: Thematic List of Publications," Department of Sociology, Lancaster University, http://www.lancs.ac.uk/fass/centres/css/ant/ant .htm. For discussion, see Simon Schaffer, "The Eighteenth Brumaire of Bruno Latour," Studies in History and Philosophy of Science 22, no. I (March 1991): 174-92. See also Bruno Latour, Reassembling the Social: An Introduction to Actor-Network-Theory (Oxford, 2005), esp. 87-120; Dant, Materiality and Society. We should also note the difficulty of integrating historical formations of power and culture in an analysis primarily concerned with reconstructing a network of actors and actants at a specific moment in time.
} 
the moderns for having neglected or altogether ignored them. The historical neglect of the "missing masses" is traced to a constitutional defect at the heart of modernity: the hegemony of the Cartesian subject and an object-alien view of the world that from the Enlightenment has sealed off politics and society from the material and natural world. ${ }^{34}$

It is perhaps ironic that a theory like ANT, so concerned with resisting grand narratives and abstractions (like "society"), draws on such a flat view of modern history. Yet modernity consists of competing traditions. There was no single discourse of things. Rather than posit a succession of mutually exclusive eras-objectaware pre-Enlightenment cultures followed by object-alien modernity and then a more object-centered present era-a first step would be to inquire into the genealogy of things.

"Things" were certainly in flux in the eighteenth century, but the flow was not all in one direction. For some, things triggered anxieties of dehumanization and dependence. For others, they were sources of knowledge and a new social order. It is hard to see a general turning away from things, as presumed by Latour and others. While materiality largely disappears from the household economy in Adam Smith's Wealth of Nations (1776), things found a new voice in commercial exchange. ${ }^{35}$ Power and status now derived from control over possessions rather than over persons. ${ }^{36}$ Indeed, the eighteenth century gave birth to a new genre of "thingbiographies." Here, teapots, a guinea, a dog, and a black coat came alive to describe people's foibles and cruelty. In advertisements, lost things "cried out" for their owners. These "it-narratives" were about "the soul of the thing," as Jonathan Lamb has put it. ${ }^{37}$ They are examples of the "excess" things carried over and above being a commodity with a price. Possessions lost (or stolen) retained a sense of the owner's identity. Eighteenth-century literature explored the porous boundaries between object and subject. Moll Flanders is consumed by her desire for clothes and objects, which takes over her subjecthood. Sexual desire could turn the body into a thing. Conversely, in the process of circulation, objects absorbed human qualities.

Authors were worried what fashion, printing, and the commodification of prose were doing to their standing and used the autobiography of things to satirize the marketplace. ${ }^{38}$ But these narratives also offer telling accounts of the more general

\footnotetext{
${ }^{34}$ Latour, "Dingpolitik."

${ }^{35}$ For example, the economic sociologist Swedberg presents Adam Smith's work as a sharp break with older traditions in which the household had occupied a central place; see Richard Swedberg, "The Centrality of Materiality: Theorizing the Economy from Xenophon to Home Economics and Beyond," Sociologica, no. 1 (2008), http://www.sociologica.mulino.it/doi/10.2383/26567. See also Daniel Miller's comment in the same issue (http://www.sociologica.mulino.it/doi/10.2383/26569). There were, however, also other trends, such as Kames's recognition of the impact of material culture on the social sphere and, later, in popular political economy by Harriet Martineau.

${ }^{36}$ Werner Sombart, Luxus und Kapitalismus (Munich, 1912).

${ }^{37}$ Jonathan Lamb, “The Crying of Lost Things," ELH: English Literary History 71, no. 4 (Winter 2004): 949-67, quote at 953. Such myths of an uprising of everyday things against people also featured in older cultures; see Walter Krickeberg, Märchen der Azteken und Inkaperuaner, Maya und Muisca (Jena, 1928).

${ }^{38}$ Christopher Flint, "Speaking Objects: The Circulation of Stories in Eighteenth-Century Prose Fiction," PMLA: Publications of the Modern Language Association of America, no. 113 (March 1998): 212-26.
} 
ambivalence of what objects are and do to people once they enter into a relation of ownership. Objects here are, precisely as Latour has written for the present era, "more interesting, variegated, uncertain, complicated, far reaching, heterogeneous, risky, historical, local, material and networky." ${ }^{39}$ Above all, things were considered risky. One motivation behind today's rediscovery of materiality is that things have always been with us (and part of us) but that we have been neglectful owners. Surely, things deserve better. Adopting a more humble, caring attitude to things will make for a more realistic, ecologically safer way of dealing with problems in human-nonhuman relations. ${ }^{40}$ If eighteenth-century literature has a lesson, by contrast, it is that giving things greater voice can have troubling outcomes. The objects "who" talked about their lives in commercial circulation ridiculed human vanity, selfishness, and ignorance. As Lamb has observed, the "enlargement of sympathy discloses relations that are neither comfortable nor sociable."41

It-narratives were part of a larger preoccupation with things that runs across the modern period. William Blackstone devoted the second and longest book of his Commentaries on the Laws of England (1765-69) to Of the Rights of Things, which drew distinctions between a host of things, from movable things versus land to domestic versus wild animals. It also offered astute observations on how things have left their imprint on human behavior-the transmission of property through inheritance, for instance, was said to make people good citizens, setting "the passions on the side of duty." 42 At a time of growing debate about slavery, the boundaries between things and persons were inevitably contested. Material objects and their polite use as well as ownership were a running thread in the philosophical and advice literature on respectability, manners, and civility. This is well known among eighteenth-century historians, but how little of this has found its way into the social sciences is further evidence of how underdeveloped the exchange between these fields remains.

It is difficult and probably unwise to try to paint a single, unilinear history of things. Some scholars point to Kant or Locke and suggest that they reveal a fundamental difference between an object-indifferent, subject-centered West and a more thing-friendly East. ${ }^{43}$ Whether individual thinkers can stand in for entire cultures is questionable. We lack the sustained comparative studies for such grand claims. What we have suggests a more complicated picture. Anxieties about things were nothing new or unique to eighteenth-century Britain. Many scholars who have studied material culture have found contemporaries warning of a new tyranny of things in their particular period and country. We should resist the temptation of claiming a revolution in a particular time and place. Renaissance Italy had a

\footnotetext{
${ }^{39}$ Latour, "Dingpolitik."

${ }^{40}$ Why presume that things would necessarily want us to treat them more fairly? Perhaps, in the world of things, an altogether different value system rules from that of humans? Nor is it clear what fairness or rights would mean for things, how these would be adjudicated, and by whom or what.

${ }^{41}$ Jonathan Lamb, "Modern Metamorphoses and Disgraceful Tales," Critical Inquiry 28, no. 1 (Autumn 2001): 133-66.

${ }^{42}$ Blackstone, Commentaries on the Laws of England (London, 1765-69), bk. 2, chap. 1. The integration of law into historical studies of consumption remains rare. For exceptions, see Margot C. Finn, The Character of Credit: Personal Debt in English Culture, 1740-1914 (Cambridge, 2003); Bronwen Morgan and Frank Trentmann, eds., "The Politics of Necessity," special issue, Journal of Consumer Policy 29, no. 4 (December 2006).

${ }^{43}$ Van Binsbergen, "Introduction," in van Binsbergen and Geschiere, Commodification, 30-36.
} 
lively culture of shopping and commodity credit that raised fears of social dislocation. ${ }^{44}$ In late Ming China, novels like Chin P'ing Mei (The plum in the golden vase, 1618) warned of the dangers of corruption lurking in objects used excessively or inappropriately. ${ }^{45}$ After the Civil War, American commentators worried that a new a cult of things was sapping personal character and public spirit. ${ }^{46}$ Instead of viewing these individually in terms of sharp breaks or novelty as national historians have done, these discourses are perhaps better viewed as members of the same family, articulated through different intellectual and literary traditions but with shared concerns nonetheless.

What set eighteenth-century Britain, and subsequently also the United States, apart was less a hostile or object-alien attitude than a set of positions that embraced things as positive agents in the advance of civilization. Moral critics no longer controlled the field: they now had to reckon with vocal supporters of consumption. Some roots of this revalorization can be traced back to the Renaissance and the Enlightenment. As Harold Cook has shown, Dutch explorers and scientists came to champion a more concrete, material form of knowledge in which, instead of distant contemplation, personal acquaintance with nutmeg, tea, tulips, and other things became critical. Touch, taste, and smell were prized. Detailed description lay at the heart of this "tasteful objectivity." 47

The upgrading of material things spread to other parts of public life and knowledge too. It was from within this Dutch context that Mandeville developed his defense of material self-interest as a source of public benefit in his controversial Fable of the Bees. An appreciation of things, self-interest, and sociability were to become entwined in the culture of exchange. In eighteenth-century Britain, writers from Barbon to Adam Smith began to imagine that the pursuit of goods might have benign effects, including drawing the poor into commercial civil society. ${ }^{48}$ The discourse of respectability and decorum promised stability in the midst of flux. It offered a hierarchical society a hierarchy of taste: more, new things did not have to lead to social disorder as long as they were consumed appropriately. By the early nineteenth century, the cynical, dystopian outlook of it-narratives, in which things told of their careless, self-centered owners who sold them, lost them, or pawned them, had given way to a more positive, educational genre in which dolls and whipping tops explained to children the reciprocal nature of respect and caring: if you treat things with care, you will be treated well too. ${ }^{49}$

If anything, these moderns were placing too much trust in things, not too little. The civilizing effect of things became an integral part of the imperial project of

${ }^{44}$ Evelyn Welch, Shopping in the Renaissance: Consumer Cultures in Italy, 1400-1600 (New Haven, CT, 2005).

${ }^{45}$ David T. Roy, trans., The Plum in the Golden Vase (Princeton NJ, 1993-); Craig Clunas, Superfluous Things: Material Culture and Social Status in Early Modern China (Chicago, 1991), and Empire of Great Brightness: Visual and Material Cultures of Ming China, 1368-1644 (London, 2007).

${ }^{46}$ Brown, Sense of Things.

${ }^{47}$ Harold J. Cook, Matters of Exchange: Commerce, Medicine, and Science in the Dutch Golden Age (New Haven, CT, 2007), 40.

${ }^{48}$ Christopher Berry, The Idea of Luxury (Cambridge, 1994); Maxine Berg and Elizabeth Eger, eds., Luxury in the Eighteenth Century: Debates, Desires and Delectable Goods (Basingstoke, 2003).

${ }^{49}$ Lynn Festa, "The Moral Ends of Eighteenth- and Nineteenth-Century Object Narratives," in The Secret Life of Things: Animals, Objects, and It-Narratives in Eighteenth-Century England, ed. Mark Blackwell (Lewisburg, PA, 2007). 
commerce, Christianity, and civilization. If becoming used to more material possessions would habituate children to look after things and people and teach the domestic poor self-discipline and industry, the same logic motivated missionaries and imperialists in nineteenth-century Africa.$^{50}$ Introduce Western clothes, tea, cooking utensils, and ornaments, and the things would steer the natives from superstition and sloth to a Christian regime of domestic economy and self-improvement. Africans would have been surprised to hear that Western Europeans were object-alien in this period.

\section{CHOICE AND PRACTICE}

In the past decade, the concepts of choice and individualism have been subjected to critique across the human sciences. Broadly speaking, revisionism has worked in three directions. One group, coming from within economics and psychology, has qualified the model of rational choice, emphasizing that rationality is "bounded," that choice can be "myopic," and that people prefer to minimize loss rather than maximize gain. ${ }^{51}$ Ultimately, however, these revised models remain anchored in an instrumental individualist view of human action. A second group has looked at routines, habits, and practices that altogether break with the paradigm of individual, momentary choice; people, for example, choose food in a shop, but the fairly consistent and slow-to-change food preferences in many societies suggest something other than a momentary calculation of costs and benefits. Consumption involves many "ordinary," everyday practices that were obscured in an earlier focus on shopping and conspicuous consumption: gardening, washing, listening to the radio, practicing hobbies. Finally, there have been attempts by a third group to broaden the concept of choice and to recapture richer historical meanings that were lost in the hegemonic rise of rational choice after the Second World War. It is the last two groups that are of interest here.

Choice retains a curious, dominant place in historical studies of consumption, and this has affected the type of things studied as material culture. Some goods have received interest as heirlooms, but most goods studied are ones that have been bought new in the marketplace. Twenty-five years ago, Neil McKendrick, John Brewer, and J. H. Plumb presented eighteenth-century England as the site of a consumer revolution..$^{52}$ More and more people, servants as well as lords, acted out their choice as consumers in the marketplace. Here was a proto-nation worthy of Thatcher's Britain. McKendrick's thesis has attracted much debate, opposition, and refinement. Commercialization had longer roots, some have pointed out.

\footnotetext{
${ }^{50}$ Jean Comaroff and John Comaroff, "Colonizing Currencies: Beasts, Banknotes, and the Color of Money in South Africa," in van Binsbergen and Geschiere, Commodification, 145-73; Timothy Burke, Lifebuoy Men, Lux Women: Commodification, Consumption, and Cleanliness in Modern Zimbabwe (Durham, NC, 1996).

${ }^{51}$ Herbert A. Simon, Models of Bounded Rationality (Cambridge, 1982); Avner Offer, The Challenge of Affluence: Self-Control and Well-Being in the United States and Britain since 1950 (Oxford, 2006); Daniel Kahneman and Amos Tversky, eds., Choices, Values, and Frames (Cambridge, 2000).

${ }^{52}$ McKendrick, Brewer, and Plumb, Consumer Society. For the cold-war context, see John Brewer, "The Error of Our Ways: Historians and the Birth of Consumer Society,” Working Paper no. 012 (Cultures of Consumption, London, 2004), http://www.consume.bbk.ac.uk/publications.html\#workingpapers.
} 
Others have painted a more pessimistic picture of the standard of living. ${ }^{53}$ Still, there is little denying that the terms of debate remain those set by McKendrick.

John Styles has provided the most sustained, critical examination of McKendrick's thesis to date. ${ }^{54}$ Styles broadly supports the optimistic picture of the spread of new clothes and other material possessions across society. At the same time, he traces the flow of goods to "plebeian consumers," not to choice and markets but to charity, gifting, inheritance, and secondhand provisioning. The practice of pawning had been noted by earlier scholars, but Styles surveys the whole network of acquisition, appropriation, and passing-on that flourished outside or alongside shops. ${ }^{55} \mathrm{He}$ groups these practices together as "involuntary consumption." This is useful as a contrast to the idea of people as shoppers. It complements research that has highlighted indirect and collective dimensions of shopping, which frequently involved intermediaries like servants, family members, or slaves or group outings. ${ }^{56}$

Analytically, however, involuntary consumption is self-limiting, defining itself negatively against an idea that choice means individual, voluntary action. It switches sides but remains within the analytical field set down by rational choice. Involuntary consumption might refer to someone on a hunger strike being force-fed, but it fails to capture the interactive dimensions of trust, reciprocity, and solidarity that are involved in receiving charity or handing down clothes. ${ }^{57}$ Renting a room furnished with a bed, a teapot, and other consumer items involves a mix of first- and second-order choices - if tenants had not wanted teapots, landlords would presumably not have provided them. By trying to reclaim the eighteenth century from the clutches of a market model of choice, involuntary consumption also minimizes the continuities of alternative systems of provisioning in our present. Many things that people consume today are not freely bought in the marketschool meals, roads, furnished apartments, family dinners, or the advertisements that are sliced between the action in a sports match one has chosen to watch.

"Modern consumer goods are cheap, disposable, infrequently repaired and quickly worthless," Styles writes. In the eighteenth century, by contrast, goods were "costly, durable, much-repaired, and readily marketed second-hand." ${ }^{8}$ This is, of course, true for certain goods like clothes in early twenty-first-century Britain, but even this trend is very recent and uneven and hardly typical of modern consumer culture. Darning, sewing, knitting, and handing down clothes were prominent practices for most of the twentieth century. In a highly "modern" society like Japan, goods are not simply tossed out because something new arrives in the household. American garages are full of second, even third units of consumer

${ }^{53}$ See Robert Malcolmson, Life and Labour in England, 1700-1780(London, 1981); Adrian Randall and Andrew Charlesworth, eds., Markets, Market Culture and Popular Protest in Eighteenth-Century Britain and Ireland (Liverpool, 1996).

${ }^{54}$ Styles, Dress of the People.

${ }^{55}$ Beverly Lemire, Fashion's Favourite: The Cotton Trade and the Consumer in Britain, 1660-1800 (Oxford, 1991).

${ }^{56}$ Ellen Hartigan-O'Connor, "Collaborative Consumption and the Politics of Choice in Early American Port Cities," 125-50; Claire Walsh, "Shops, Shopping and the Art of Decision Making in Eighteenth-Century England," 151-78; and Ann Smart Martin, "Ribbons of Desire: Gendered Stories in the World of Goods," 179-200, all in Vickery and Styles, Gender, Taste, and Material Culture.

${ }^{57}$ Conversely, shopping and other forms of purchase include not only "voluntary" features.

${ }^{58}$ Styles, Dress of the People, 31. 
durables. Modern goods may be cheap in one context but valuable and meaningful in another. There is a cottage industry of social science studies on secondhand and charity shops, collecting, recycling, yard sales, family gift networks, and hoarding and unhoarding. ${ }^{59}$

The limitations of individual choice, then, are not something peculiar to the period before the nineteenth and twentieth centuries. Indeed, in sociology and science and technology studies, the past few years have seen a burst of interest in "ordinary" consumption. Instead of choice, a main inspiration here is the theory of practice and an interest in the evolution over time of practices like eating, walking, or washing the body. A practice is the result of doings and sayings that are linked together through a series of understandings, rules, tasks, and emotions. ${ }^{60}$ Some are daily routines, but there are also practices that reproduce these linkages through less frequent performances, such as skiing or celebrating Carnival. Medieval and early modern historians are, of course, familiar with "customs." Historians writing about "modern" consumer culture, however, easily tend to forget these habitual dimensions. Arguably, this blind spot has its roots in a "modernist" view that sees custom/tradition and commercial society/modernity as sequential orders, the latter colonizing and exterminating the former, as in E. P. Thompson's "moral economy." ${ }^{\prime 1}$ It echoes nineteenth-century ideas about human evolution and modernization. Jean-Baptiste Lamarck believed there was an inverse relationship between human intelligence and the power of habits over actions. Émile Durkheim and Max Weber too saw habits and rituals as the sign of traditional societies in contrast to the reflexive thought and conscious action of modern societies. $^{62}$

Have habits and routines declined in the process of modernization? For Norbert Elias and Henri Lefebvre, modernity stands for the growth of such disciplining routines. Lefebvre saw modern society as a vast form of "dressage" that "broke in" humans through its social institutions, rites of conduct, and business: liberty

\footnotetext{
${ }^{59}$ Nicky Gregson and Louise Crewe, Second-Hand Cultures (Oxford, 2003); Inge Maria Daniels, "Scooping, Raking, Beckoning Luck: Luck, Agency and the Interdependence of People and Things in Japan," Journal of the Royal Anthropological Institute, no. 9 (December 2003): 619-38; Alison Clarke, "Mother Swapping: The Trafficking of Nearly New Children's Wear," in Commercial Cultures: Economics, Practices, Spaces, ed. Peter Jackson, Michelle Lowe, Daniel Miller, and Frank Mort (Oxford, 2000); Russell W. Belk, Collecting in a Consumer Society (London, 2001); Steven M. Gelber, Hobbies: Leisure and the Culture of Work in America (New York, 1999); William Davies King, Collections of Nothing (Chicago, 2008); David J. Ekerdt and Julie F. Sergeant, "Family Things: Attending the Household Disbandment of Older Adults," Journal of Aging Studies 20, no. 3 (September 2006): 193-205.

${ }^{60}$ Theodore R. Schatzki, Karin Knorr-Cetina, and Eike von Savigny, eds., The Practice Turn in Contemporary Theory (London, 2001); Alan Warde, "Consumption and Theories of Practice," Journal of Consumer Culture 5, no. 2 (July 2005): 131-53; Jukka Gronow and Alan Warde, eds., Ordinary Consumption (London, 2001); Elizabeth Shove and Mika Pantzar, "Consumers, Producers and Practices: Understanding the Invention and Reinvention of Nordic Walking," Journal of Consumer Culture 5, no. 1 (January 2005): 43-64.

${ }^{61}$ E. P. Thompson, "The Moral Economy of the English Crowd in the Eighteenth Century," Past and Present, no. 50 (February 1971): 76-136. For critiques, see Frank Trentmann, "Before 'Fair Trade': Empire, Free Trade, and the Moral Economies of Food in the Modern World," Environment and Planning D: Society and Space 25, no. 6 (2007): 1079-1102.

${ }^{62}$ See Brown, Sense of Things, chap. 2; Elizabeth Shove, Frank Trentmann, and Richard Wilk, eds., Time, Consumption, and Everyday Life (Oxford, 2009), forthcoming.
} 
was mainly an illusion. ${ }^{63}$ There are, however, also ways of thinking about habits and intelligence as complementary. In his Psychology (1892), William James approached habits and reflexive thought as partners: the more bits of daily life were handed over to routines, the more it freed up the "higher" faculties of mind.

Practices are useful for reconnecting consumption to the study of things, materials, and technologies without falling into the trap of technological determinism. As Elizabeth Shove and colleagues have emphasized, studies often allude to the importance of novelty for consumer culture but rarely examine how new things come about, how their material composition changes, and how this affects social life. ${ }^{64}$ Products have ideas of how they will be used designed into them; future practices are "scripted." 65 But they are also subject to local contexts of "appropriate" use. Following routines, like the shift from bathing to showering, reveals how patterns of everyday life are reproduced, adapted, and changed. ${ }^{66}$ The focus is not just on what things mean but on how things are done.

Practices have a dynamic force of their own, creating sensations, competencies, and plans of doing more or doing things differently. They are entangled in a creative interplay with materiality. Practice research gives attention to the materials out of which products are composed-new materials, like plastics, introduce "new concepts of performance" and carry new cultural meanings. Studies of home improvement in Britain, for example, show how new products and tools like fastdrying paint or quick-fix plumbing have democratized competence (away from specialized decorators). These are examples of "delegation"-that is, how certain functions are conferred from human actors to tools and technologies. A door with an automatic closing device, one of Latour's examples, both takes over from people the job of closing the door and encourages them to think they should close that door if the mechanism happens to fail. At the same time, the use of technologies (new and old) depends on people's competencies-and these have histories. Existing practices can trigger new projects. Kitchen renovations, in this view, do not simply arise from a surrounding materialist culture advertising shiny new goods but are the accomplishment of specific practices. ${ }^{67}$

Practices thus look beyond possessions. Instead of taking either object or individual as its starting point, research on practices focuses on how users, things, tools, competence, and desires are coordinated. The life of objects, in other words, is not prior to or independent of social practices but codependent. This also means that value is not based in a product or its meanings but in how it is put to use.

${ }^{63}$ Henri Lefebvre, Rhythmanalysis: Space, Time and Everyday Life (London, 2004), 40-41. See also Fernand Braudel: "I think mankind is more than waist-deep in daily routine. Countless inherited acts, accumulated pell-mell and repeated time after time to this very day, become habits that help us live, imprison us, and make decisions for us throughout our lives" (Afterthoughts on Material Civilization and Capitalism [Baltimore, 1977], 7).

${ }^{64}$ Elizabeth Shove, Matthew Watson, Martin Hand, and Jack Ingram, The Design of Everyday Life (Oxford, 2007).

${ }^{65}$ Harvey Molotch, Where Stuff Comes From: How Toasters, Toilets, Cars, Computers, and Many Other Things Come to Be as They Are (New York, 2005).

${ }^{66}$ Elizabeth Shove, Comfort, Cleanliness and Convenience: The Social Organisation of Normality (Oxford, 2003).

${ }^{67}$ Shove et al., Design of Everyday Life; Martin Hand and Elizabeth Shove, "Orchestrating Concepts: Kitchen Dynamics and Regime Change in Good Housekeeping and Ideal Home, 1922-2002," Home Cultures 1, no. 3 (November 2004): 235-57. 
The "search for the source of stuff," as Harvey Molotch has argued, needs to look for the "continuous stroking between object and action" that stabilizes things. An object such as the chair acquires its durability because it has become tightly connected with practices, norms, and symbolic meaning. ${ }^{68}$

A theoretical turn to practices, then, raises a host of historical questions for the evolution of material culture, especially about the different "careers" of consumption practices, about the changing ways in which people have become committed (and uncommitted) to practices, and about the role of technologies, competencies, and expectations of use in steering their development. The question is no longer whether people in different historical contexts have more or fewer goods or whether they are involuntary or voluntary consumers, but how they use goods in changing patterns.

It would be shortsighted, however, to throw the baby out with the bathwater and suspend consideration of choice altogether. Choice deserves a broader conceptual and historical frame. "Rational choice," Mary Douglas has emphasized, is problematic not because people are not rational but because the economistic model trivializes the many social and moral layers of rationality at work when people make choices. These range from buying goods for oneself, friends, or family to choosing things for a dinner party —indeed, making choices about what kind of dinner party one wants. "These sort of choices are the mainspring of culture," Douglas writes. "They are not trivial choices at all, they are absolutely fundamental for the whole life of a people." Choice becomes more, not less, important in this view: "In the end, the consumer's choices should be seen as moral judgments about everything: about what a man is, about what a woman is, how a man ought to treat his aged parents, how much of a start in life he ought to give his children, how he expects himself to grow old." ${ }^{99}$

Pragmatism offers a useful argument for seeing choice and routine as interconnected rather than as opposites. Habits, John Dewey argued, were not just "means, waiting, like tools in a box, to be used by conscious resolve." They "constitute the self," forming "our effective desires" and furnishing us with "our working capacities." It would be a "perilous error to draw a hard and fast line between action into which deliberation and choice enter and activity due to impulse and matter-of-fact habit." Actions have consequences and thus involve reflecting on things previously done as a "matter of course." At the same time, "every reflective choice tends to relegate some conscious issue into a deed or habit henceforth taken for granted and not thought upon." Habits and choice thus feed each other. Dewey and his followers in the home economics movement rejected utilitarianism. Rationality was "not a ready-made antecedent which can be invoked at will and set into movement." Rather, it was an ongoing developmental process of testing, learning, and searching. People had to manage a permanent overflow of preferences

\footnotetext{
${ }^{68}$ Molotch, Stuff, 2.

${ }^{69}$ Mary Douglas, "Why Do People Want Goods?" in Understanding the Enterprise Culture: Themes in the Work of Mary Douglas, ed. Shaun Hargreaves Heap and Angus Ross (Edinburgh, 1992), 19-31.
} 
and biases. Choice therefore becomes a deliberative search for "a way to act, not for a final terminus." 70

These approaches are interesting in their own right, but they are also a useful reminder that history consists of rival traditions of choice and consumption. In the past two decades, studies of shopping and collecting have highlighted the advancing validation of goods and consumption in Victorian and Edwardian Britain. ${ }^{71}$ Anxieties about the demoralizing effects of consumer culture never vanished but were a reaction to a growing embrace of things. Shopping, window-shopping, and flaneuring were core practices that opened up civic spaces, especially for women. What set Britain aside from societies on the Continent and parts of the United States where taxes were levied on department stores was an increasingly dominant acceptance of choice and consumption as vital to the public interest. The above discussion suggests that to understand this process, we also need to place these domestic and extradomestic material practices within a broader context of the intellectual traditions and political economy that reframed choice and the public identity of consumers. The association between consumers, the public interest, and social ethics in free trade culture in Britain is one such context. ${ }^{72}$ The dominant regime of free trade created a new favorable climate for consumers in public life that, in turn, made for a less antagonistic and less regulatory environment and for a civic culture that was more accepting of choice and things. Free trade promised material improvement without the excesses of materialism. Studies of material culture and political economy, clearly, stand only to gain from one another.

\section{MATERIAL POLITICS}

To expand the focus from possessions to things and from having to doing has implications for political history. Historians have long noted how objects have acted as political symbols, vehicles of community, ingredients of the public sphere, and instruments of political communication. ${ }^{73}$ The approaches introduced earlier

\footnotetext{
${ }^{70}$ John Dewey, Human Nature and Conduct: An Introduction to Social Psychology (New York, 1922), $25,67,193,196,279$. It is problematic to view choice and the consumer as recent products of “advanced liberal” governmentality. See esp. Nikolas Rose, Powers of Freedom: Reframing Political Thought (Cambridge, 1999). Also see Mark Bevir and Frank Trentmann, "Civic Choices: Retrieving Perspectives on Rationality, Consumption, and Citizenship," in Citizenship and Consumption, ed. Kate Soper and Frank Trentmann (Basingstoke, 2007), 19-33; John Clarke, Janet E. Newman, Nick Smith, Elizabeth Vidler, and Louise Westmarland, Creating Citizen-Consumers: Changing Publics and Changing Public Services (London, 2007).

${ }^{71}$ Erika D. Rappaport, Shopping for Pleasure: Women and the Making of London's West End (Princeton, NJ, 2000); Cohen, Household Gods; Judith R. Walkowitz, City of Dreadful Delight: Narratives of Sexual Danger in Late-Victorian London (Chicago, 1992); Peter J. Gurney, "The Sublime of the Bazaar: A Moment in the Making of a Consumer Culture in Mid-Nineteenth Century England," Journal of Social History 40, no. 2 (Winter 2006): 385-405. For comparisons, see Geoffrey Crossick and Serge Jaumain, eds., Cathedrals of Consumption: The European Department Store, 1850-1939 (Aldershot, 1999).

${ }^{72}$ Frank Trentmann, Free Trade Nation: Commerce, Consumption, and Civil Society in Modern Britain (Oxford, 2008).

${ }^{73}$ James Epstein, Radical Expression: Political Language, Ritual, and Symbol in England, 1790-1850 (Oxford, 1994); Daniel Boorstin, The Americans: The Democratic Experience (New York, 1973); T. H. Breen, The Marketplace of Revolution: How Consumer Politics Shaped American Independence (New York, 2004); Jürgen Habermas, The Structural Transformation of the Public Sphere (1962; repr., Cambridge, 1989). See also Brian Cowan, The Social Life of Coffee (New Haven, CT, 2005); Lisa Tickner,
} 
prompt a more profound reassessment of the material essence of politics. Things appear at once more integral to political processes and sensibilities and more fragile, precarious, and politicized than in conventional accounts. Instead of starting with political actors who then appropriate objects for symbolic effects, Heidegger and Merleau-Ponty see the material world as woven into people's bodies, identities, and actions. Things, in other words, recruit us into politics as much as we recruit them. And, in addition to highly visible objects, these include the hidden material networks, technologies, and relationships that shape everyday life. The evolving entwining of things and users in practices finally shakes assumptions about the stability, order, and disciplinary power of things. Late or neo-Foucauldians have looked at how state power can be objectified. Scholars interested in "evocative objects," by contrast, have stressed how things act as sources of individual self and emotional stability. Both these accounts distract from the more fluid and troublesome life of things. Things are not just friendly companions or instruments of power. Things are also trouble. They break down. They cause us grief, anger, or bewilderment. How they work depends on how people use them, and uses differ on the ground. For politics, this means conflict and resistance, not merely discipline and control.

In contrast to most histories of material culture, in which an interest in culture tends to neglect politics, the return to things in the social sciences puts politics center stage. Taking things seriously as knots of social knowledge and action raises questions about the liberal paradigm of politics associated with subject-centered forms of autonomy and critical reason. The most passionate call for a new politics has come from scholars keen to raise things to the level of actors themselves. For Latour, the resurgence of objects as things means the end of modern politics defined through political representation and deliberative reason: "The parenthesis that we can call the modern parenthesis during which we had, on the one hand, a world of objects, Gegenstand, out there, unconcerned by any sort of parliament, forum, agora, congress, court and, on the other, a whole set of forums, meeting places, town halls where people debated, has come to a close." ${ }^{74}$ For Latour, Hobbes, Rousseau, Rawls, and Habermas are symptomatic of "the strong objectavoidance tendency" of modern political philosophy. This critique picks up where Heidegger left off. Heidegger had emphasized the original political etymology of Ding/Thing used to denote Thingstaetten and other assemblies. Heidegger too called for a less utilitarian approach, a more meditative Gelassenheit or "releasement" toward things. ${ }^{75}$ Latour extends this concerning attitude to the political realm. Modern politics, Latour argues, has had a lopsided view of representation concerned with how best "to gather the legitimate people around some issue." What this tended to ignore was how to represent "objects of concern" and bring them into those representative arenas. The liberal model of politics needs to be complemented by a new Dingpolitik in which objects rejoin people in processes of representation.

The Spectacle of Women (London, 1987), chaps. 2-3; Trentmann, Free Trade Nation, chap. 2.; James Thompson, "Pictorial Lies? Posters and Politics in Britain, 1880-1914," Past and Present, no. 197 (November 2007): 177-210.

${ }^{74}$ Bruno Latour, "Why Has Critique Run out of Steam: From Matters of Fact to Matters of Concern," in Things, ed. Bill Brown (Chicago, 2004), 151-73, quote at 161.

${ }^{75}$ Martin Heidegger, Discourse on Thinking (New York, 1966), 54. 
Latour is careful to note that in practice these two modes of representation have always been mixed. Still, it is difficult not to read his manifesto for a Dingpolitik as an indictment of modern political culture that reaches well beyond particular philosophers. Between the lines there lingers a sense of nostalgia for a time when things had their political place. To call for a new beginning in which "politics is no longer limited to humans" but "incorporates the many issues to which they are attached" implies that in the modern period it had been just so limited. ${ }^{76}$

We have already noted some of the problems with this rather monochromatic view of modernity supposedly so divorced from things. It is difficult to see the procedures of representative politics as the dominant concern of "modern" societies outside a small core of liberal countries in the northwest of Europe. Even within the so-called heartland of the Westminster model, any perusal of parliamentary papers and election materials would quickly bring out just how much politics incorporated the matters of concern to which representatives, voters, and state and business were attached, from empire, land, and railways to infrastructures and public health. Outside formal politics, the rise of anthropology in the late nineteenth century, exhibiting the material civilization of indigenous cultures, and the string of writers, intellectuals, and artists trying to capture the social force of things-from Henry James to George Perec and Pablo Neruda, from Dewey to Heidegger and the Annales school all the way to the late Robert Rauschenbergpoint to a much more vibrant engagement with things than suggested by the thesis that modernity introduced a sharp divide between human and nonhuman, "society" and nature.

Before simply rejecting Latour as problematic history, however, we might historicize his concerns into questions for research. How have things impinged on political processes, spaces, and sensibilities in the past? What has been the place accorded to things in different traditions? To what degree has a liberal model of parliamentary representation favored the exclusion or inclusion of certain dimensions of the material world and shaped the representation of their concerns? What can attention to materiality tell us about power, its changing force, direction, and distribution?

In modern British history, the scholars who have especially engaged with these questions have done so coming from a late Foucauldian background. There is a historiographical and biographical logic to this, in particular for Patrick Joyce and James Vernon. They are interested in how discourse and language created key categories like "the people," informed the constitution, and shaped democratic sensibilities, so they have already explored a domain of politics beyond parties and parliaments. ${ }^{77}$ The recent turn to technopolitics can be viewed as a retreat from a fascination with discourse, but it can also be read as a continuation of that intellectual project by other means, examining the creation and diffusion of political subjectivity through the apparatus of technologies.

Significantly, this corpus of work so far retains the earlier focus on the mid- and

\footnotetext{
${ }^{76}$ Latour, "Dingpolitik."

${ }^{77}$ Patrick Joyce, Visions of the People: Industrial England and the Question of Class, 1848-1914 (Cambridge, 1991), and Democratic Subjects: The Self and the Social in Nineteenth-Century England (Cambridge, 1994); James Vernon, Politics and the People: A Study in English Political Culture, c. 1815-1867 (Cambridge, 1993); James Vernon, ed., Re-reading the Constitution: New Narratives in the Political History of England's Long Nineteenth Century (Cambridge, 1996).
} 
late nineteenth and early twentieth centuries and its critique of more heroic Whiggish or social democratic narratives. Its overarching concern is how the newly dominant regime of liberalism relied on ostensibly nonpolitical instruments of rule and, especially, self-rule. Joyce, Chris Otter, and Tom Crook look at how maps, urban networks of gas and water, and the "modern cubicle" of bath and toilet have "normalized" Britons into liberal subjects practicing governmentality on themselves; Vernon's work on hunger and the school meal extends this technopolitical gaze beyond liberalism to the welfare state. ${ }^{78}$

There is much to appreciate in this work, not least its engagement with science and technology studies and with theoretical debates about the political. Ironically, from the perspective of materiality, the problem of this theory-conscious literature is perhaps not that it goes too far but that it does not go far enough. Its interest in materiality remains tied to a late Foucauldian interest in the disciplining force of technology. The material world appears a fairly pliant instrument of rule. Sewers, roads, and maps are of interest to Joyce because of the "technosocial solutions to political questions that were to be found [there]." The " "political' nature of these solutions," he continues, "lay precisely in the way they were realized as 'technical' and so outside the political." ${ }^{79}$ These are strong assumptions. Why presume separate political and technical worlds; why presume that technologies and networks externalized political processes rather than penetrated each other? And why necessarily present these technological processes as "solutions"?

As in Foucault and Nikolas Rose, perhaps the most influential interpreter of governmentality ideas in English, historical studies of technopolitics emphasize the power of experts, the effectiveness of disciplinary techniques, and the ordering of power. ${ }^{80}$ While these studies are intended as critiques of governmentality and its various instruments (the school meal, the toilet, the market), they run the risk of reinscribing a view of the world according to experts rather than recovering the world as lived by people. ${ }^{81}$ Theoretically, they acknowledge that the material is never durable on its own but requires ongoing maintenance. ${ }^{82}$ In practice, however, governmentality's concern with order and experts leads to relative indifference to what users actually did with (old and new) things and technologies or with the political tensions and conflicts that arose from competing understandings of appropriate use between users and experts.

\footnotetext{
${ }^{78}$ Patrick Joyce, The Rule of Freedom: Liberalism and the Modern City (London, 2003); Chris Otter, "Making Liberalism Durable: Vision and Civility in the Late Victorian City," Social History 27, no. 1 (January 2002): 1-15; Tom Crook, "Power, Privacy and Pleasure: Liberalism and the Modern Cubicle," Cultural Studies 21, no. 4/5 (July 2007): 549-69; Thomas Osborne, "Security and Vitality: Drains, Liberalism and Power in the Nineteenth Century," in Foucault and Political Reason, ed. Andrew Barry, Thomas Osborne, and Nikolas Rose (Chicago, 1996), 99-121; James Vernon, "The Ethics of Hunger and the Assembly of Society: The Techno-Politics of the School Meal in Modern Britain," American Historical Review 110, no. 3 (June 2005): 693-725. See also Timothy Mitchell, Rule of Experts: Egypt, Techno-Politics, Modernity (Berkeley, CA, 2002).

${ }^{79}$ Joyce, Rule of Freedom, 7.

${ }^{80}$ Nikolas Rose, Powers of Freedom: Reframing Political Thought (Cambridge, 1999).

${ }^{81}$ David Edgerton, "Creole Technologies and Global Histories: Rethinking How Things Travel in Space and Time," Journal of History of Science and Technology, no. 1 (Summer 2007), http://www .johost.eu/ ?oid $=2 \&$ act $=$ \&area $=4 \&$ ri $=1$ \&itid $=$; Daniel Miller, "Turning Callon the Right Way Up," Economy and Society 31, no. 2 (May 2002): 218-33.

${ }^{82}$ Well put, e.g., by Joyce, Rule of Freedom, 72.
} 
The treatment of urban networks illustrates both the potential insights and the self-imposed limitations of the governmentality approach and suggests how a more user- and practice-oriented approach might enrich our understanding of material politics. As Joyce rightly points out, the Victorian city "was no longer simply a metaphor for good government but its privileged site." ${ }^{\prime 3}$ Sanitary reforms and urban networks exemplify the "rule of freedom" at work. The civilizing ambition of new forms of conduct, hygiene, and private comfort was symbolized by the shift from an intermittent to constant water supply in the late nineteenth century. Joyce begins not with how people used water but with the biological vision of the city advanced by Robert Vaughan's The Age of Great Cities (1843). Subsequent reforms appear as expressions of the material and mental fusion of body and city. With running water, urban networks pumped new disciplinary powers of cleanliness and selfhood into homes. For Joyce, these interventions in personal conduct are characteristic of what he terms "liberal" rule and of the transformation of the political. The "material inculcation of privacy," he argues, "is a further instance of how the state 'subsisted in' material forms into which certain kinds of agency and knowledge are 'engineered." 84 The state came through the pipes. But it was never a visible, direct expansion of the political. Rather, Joyce argues, it was an instance of the "evacuation of the political." Crook, in his study of the cubicle, invokes similarly a "sequestration of "the political," which came with a "depoliticisation of other spheres." ${ }^{" 55}$ Indeed, Joyce sees the "agency of running water in the Victorian home" as dependent on "this separation of the political from the supposedly 'objective,' from the material, and from the technological." This separation was the ruling principle of liberal self-rule: "Interventions in the supposedly objective 'material' world of urban infrastructures therefore permitted the 'social' to operate freely, and according to its own equilibrium as a natural system." $\$ 6$

Elsewhere Joyce invokes a Foucauldian view of the mutuality between power and resistance, but there is little of this in the historical account of pipes and water. Technological networks, he acknowledges, have their flaws, but these are noted only in the abstract as part of how "liberal political reason" kept itself alive: by creating problems "around which governance might be thought and prosecuted." ${ }^{87}$ There is an appealing intellectual symmetry between the core pieces of this model. Water, sanitation, and the material world are "black-boxed" as the domain of science and technology, an idea Joyce borrows from Latour. Privatization and depoliticization work hand in hand. The home becomes a space separate from the political, in which individuals regulate themselves without interference. Throughout there is a distancing between private and public, individuals and the political, the material and the political. But is it true?

Whatever some engineers or social planners might have envisioned, urban networks never managed to black-box water as the domain of technical experts. Rather than distancing the material from the political, pipes and constant supply brought them into collision. Instead of an "evacuation of the political," cities saw an ex-

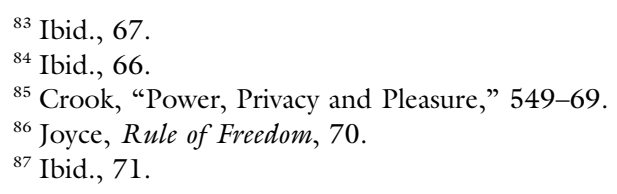


panding world of material politics. Similarly, in colonial India, the export of the metropolitan gravitation scheme ran into local antipathy, religious resistance, and environmental obstacles. ${ }^{88}$ In British cities in the late Victorian period, legal and political disputes over rates and ownership were joined by debates concerning the material hardware and use of constant supply and new conveniences like baths and water closets, including conflicts over legitimate and wasteful use, meters, and the maintenance of pipes and cisterns. New networks, with their sheer cost, deeply divided many towns into competing factions and, indeed, expert cultures. Attempts to regulate the use of privies and sewers brought a transformation of nuisance law that introduced new powers (the nuisance inspector) and new spaces for complaint and friction. ${ }^{89}$

The battles sparked by the repeated failure of constant supply reveal the gap between "liberal" ideals of equilibrium and everyday practices and politics. For Londoners, the 1890s brought repeated scarcities and the temporary suspension of constant supply; in South and East London, the "water famine" in the summer of 1895 lasted ten weeks. ${ }^{90}$ Some of the causes were natural. But disruption was also a result of material practices that never smoothly followed the engineers' script. Water companies fought endless battles against "wasteful" consumers who left their taps open to catch the water while away at work. These were not just problems created by "liberal political reason" but in part resulted from changing technologies themselves. "Water London" was carved up between eight water companies and lacked a unified circulatory network. ${ }^{91}$ Networks were far less durable than imagined. In addition to leaking pipes, poverty often conspired against "appropriate" use. Doors and fittings were stolen, neglected, or in some cases turned into cheap fuel. How people used water technologies continued to differ markedly too. For most Britons, constant supply did not come with a private bath and private toilet until the middle of the twentieth century. Bathing involved a mix of private and public, individual and familial routines, often among members of the same household. Some washed at the sink every night. Many boys took showers at school, while their sisters were washed at home in a zinc bath on Saturday afternoons. ${ }^{92}$ Even for the middle classes it is easy to exaggerate the bath as an instrument of

\footnotetext{
${ }^{88}$ See John Broich, "Engineering the Empire: British Water Supply Systems and Colonial Societies, 1850-1900," Journal of British Studies 46, no. 2 (April 2007): 346-65; David Arnold, Science, Technology, and Medicine in Colonial India, 1760-1947 (Cambridge, 2000).

${ }^{89}$ Christopher Hamlin, "Muddling in Bumbledom: On the Enormity of Large Sanitary Improvements in Four British Towns, 1855-1885," Victorian Studies 32, no. I (Autumn 1988): 55-83, and "Public Sphere to Public Health: The Transformation of 'Nuisance," in Medicine, Health and the Public Sphere in Britain, 1600-2000, ed. Steve Sturdy (London, 2002), 189-204.

${ }^{90}$ See Frank Trentmann and Vanessa Taylor, "From Users to Consumers: Water Politics in NineteenthCentury London," in The Making of the Consumer, ed. Frank Trentmann (Oxford, 2006), 53-79.

${ }^{91}$ Problems with interconnectivity continued in the twentieth century; see Vanessa Taylor, Heather Chappells, Will Medd, and Frank Trentmann, "Drought Is Normal: The Socio-Technical Evolution of Drought and Water Demand in England and Wales, 1893-2006," Journal of Historical Geography (forthcoming).

${ }^{92}$ Interview nos. 28, 33, and 386, "Family Life and Work Experience before 1918," UK Data Archive, University of Essex. Crook's own work on the cubicles shows that, in practice, such privatized spaces often existed next to circular, shared pissoirs and were vulnerable to breakdown or transgressive behavior (Crook, "Power, Privacy and Pleasure").
} 
self-rule. In 1870s Sheffield, respectable middle-class men measured their use of water as no more than the equivalent of 65 baths a year for an entire family. ${ }^{93}$

New private technologies had political spillovers. The introduction of baths, toilets, and constant supply did not make people turn away from public life to take care of their private bodies. Use, cost, and care were matters of public concern as well as private self-rule and led to political mobilization and new social movements like consumer defense leagues. Far from black-boxing them, the battles over water illustrate how a network introduced new "matters of concern" into the political arena. In London, those who favored a public takeover of the water companies, and whose demands were eventually satisfied in 1902, firmly believed that the "problem" of "water famines" was of a political nature, requiring a political, not technical, solution. Their hope rested on an explicitly political notion of the private user: as joint stakeholders, people would stop wasting water and would become responsible citizen consumers.

Urban networks and water are, of course, only one example and cannot possibly capture the range of material politics that stretches from local "nuisance" to national battles over copyright and standards of industrial design. ${ }^{94}$ Still, they allow for some suggestions. One is that to look at things and technologies in use is as important as the imagined uses scripted by experts. Modern societies, indeed, depend on a good deal of routinized practice and self-rule, but-and perhaps especially so in "liberalism"- this also means that practices have a space to diverge and evolve. The objectification of power is not something peculiar to the state. Material politics also grows from within civil society and can have a politically expansive and (to a degree) emancipatory thrust, as shown by the consumer leagues.

There are some affinities here with the older research on everyday life pioneered by Henri Lefebvre and Michel de Certeau, but with significant qualifications. Certeau also took Foucault to task for a one-sided concern with clarifying "how the violence of order is transmuted into a disciplinary technology." It was equally important "to bring to light the clandestine forms taken by the dispersed, tactical, and makeshift creativity of groups or individuals already caught in the nets of "discipline." The practices of everyday life-from cooking, walking, and reading to watching television-involved "ruses" and transgressive tactics that would potentially reveal "the network of an antidiscipline." 95 This remains a useful insight. Yet it unnecessarily sets up a divide between private consumers and public governance and commercial systems. By contrast, the above discussion shows that to take users and practices seriously means also to recognize that they leave their mark on the world of things, how things work (or fail to work), and how material is organized and distributed. People here are neither passive, disciplined dupes nor heroic agents of antidiscipline, but "co-producers" of systems of provision. ${ }^{96}$

\footnotetext{
${ }^{93}$ See Taylor and Trentmann, "Liquid Politics."

${ }^{94}$ Lara Kriegel, "Culture and the Copy: Calico, Capitalism, and Design Copyright in Early Victorian Britain," Journal of British Studies 43, no. 2 (April 2004): 233-65.

${ }^{95}$ Michel de Certeau, The Practice of Everyday Life (1974; repr., Berkeley, CA, 1984), xiv-xv; Henri Lefebvre, Critique of Everyday Life: Foundations for a Sociology of the Everyday, Volume II (1961; repr., London, 2002), and Critique of Everyday Life: From Modernity to Modernism, Volume III (1981; repr., London, 2005).

${ }^{96}$ Bas van Vliet, Heather Chappells, and Elizabeth Shove, Infrastructures of Consumption: Environmental Innovation in the Utility Industries (London, 2005).
} 
Finally, our understanding of material politics could be enriched by complementing a focus on order and rule with one on disruption and conflict. Drought is just one example of the fragility of human-material relations. Things, as Latour has stressed, should not be reduced to clear, fixed objects but appreciated for their complicated, uncertain nature. Science and technology scholars and organizational sociologists have examined high-risk accidents and system breakdowns, from nuclear disasters to train crashes and foot and mouth disease. ${ }^{97}$ The subject of disruption could be taken much further into the interstices of everyday life. The increasingly complex interdependence of systems means that modern societies are as rich in disruption as they are in routines; arguably, some disruptions have become routine, from traffic jams and canceled trains to electronic spam and queues for public services. ${ }^{98}$ Goods and technologies break down and require human elasticity and maintenance.

Disruptions bring to life the dynamic relationship between humans and things. They illuminate the fractured microhistories of routinization so often invoked in studies of governmentality but so difficult to capture with its disciplinary armature. Historical studies could helpfully pick up on older ideas of William James and Leo Stein about disruptions as moments that reveal the nature of things. When a quotidian object whose performance is taken for granted fails to work, Stein argued, its thingness becomes apparent. James used the example of looking at a landscape upside down to discuss how a break in habits can reveal otherwise hidden properties in objects; while the habitually known representational meaning of the picture is lost, other previously unnoticed aspects like shadings and texture are revealed. ${ }^{99}$ Similarly, it was droughts that brought out Victorians' diverse norms, habits, and technologies of using water. The study of breakdowns and dislocations might encourage greater respect for the fragile materiality of social life. This is not a plea to focus exclusively on disruptions or misuse at the expense of habits and their naturalization. Rather, disruptions are useful heuristic devices giving us access to the lived human experience with things and to contingent and competing patterns of use. They point to the open, evolving processes of routines and highlight the material and social processes that need to be coordinated to successfully turn practices into habits.

\section{CONCLUSION}

In the past two decades, historical work on material culture has primarily looked at objects to reveal processes of symbolic communication and identity formation. These remain valuable research questions, but they are no longer the only ones. This article has explored three additional dimensions: a conceptual broadening from objects to things, practices, and material politics. In these spheres, things appear as integral parts of relationships and subjectivities rather than as instruments of meaning appropriated by a prior subject. It has, perhaps, been unfortunate that

\footnotetext{
${ }^{97}$ Latour, Reassembling the Social; Charles Perrow, Normal Accidents: Living with High-Risk Technologies (Princeton, NJ, 1999).

${ }^{98}$ Frank Trentmann, "Disruption Is Normal: Blackouts, Breakdowns and the Elasticity of Everyday Life," in Shove, Trentmann, and Wilk, Time, Consumption, and Everyday Life.

${ }^{99}$ Brown, Sense of Things, 74-80.
} 
this point has become linked with the more controversial claim that things have "agency." Whatever we think about this stronger claim, it should not distract from the more easily acceptable proposition that things and humans are inseparably interwoven in mutually constitutive relationships.

For the study of history this poses particular challenges but also offers opportunities. The opportunities lie in a more open exchange with neighboring disciplines about the evolution of social processes, of how humans come to behave and interact as they do, and the ways in which things and technologies become integrated in practices, evolve, and dissolve. For political history in particular, attention to the changing material dimensions of politics creates bridges with histories of technology and the everyday. Material politics, in this view, is no longer a separate subdomain in which shifts in political ideas and party politics play themselves out, such as in battles over municipal reform. Nor is the material and technical a separate zone for political projects of rule. Rather, the material is recognized as a conduit of political processes that helps shape (and not just reflect) political identities, concerns, and fields of action.

Showing things greater respect also has implications for the practice of history. Traditionally, the practice of history has been exceptionally text-based. Cultural history added iconography. A turn to things would call for further extensions, complementing the study of text and symbols with that of materials and technologies. Anthropologists have discussed the costs and benefits from the turn away from a more material engagement with cultures to a more formal, text-based profession in the first half of the twentieth century. For historians, there may be gains from more open, mixed forms of research and documentation. Letting things in would expand the historical archive, the form of research training, and the kind of materials that we tend to think of as sources. The material world has too much history in it to leave it to the social sciences. 